\title{
Production and profitability of a beef herd on transitional Cymbopogon-Themeda veld receiving three levels of lick supplementation
}

\author{
L. A. Foster ${ }^{1}$, P. J. Fourie ${ }^{1 \#} \&$ F. W. C. Neser ${ }^{2}$ \\ ${ }^{1}$ Department of Agriculture, Central University of Technology, Free State, Private Bag X20539, Bloemfontein, 9300, \\ South Africa \\ ${ }^{2}$ Department of Animal, Wildlife and Grassland Sciences, University of the Free Sate, P.O. BOX 339, Bloemfontein \\ 9300 , South Africa
}

(Received 22 June 2017; Accepted 13 September 2017; First published online 10 December 2017)

Copyright resides with the authors in terms of the Creative Commons Attribution 4.0 South African Licence.
See: http://creativecommons.org/licenses/by/4.0/za

\begin{abstract}
The purpose of the study was to investigate the effects of three levels of lick supplementation on the production and reproduction of cows grazing transitional Cymbopogon-Themeda veld. The study was conducted over three years (2011-2014). A total of 150 Drakensberger cows were randomly allocated to three supplementary treatment groups. These supplementation formulations are available commercially and are typical of levels used under farming conditions. In summer Treatment 1 (T1) consisted of a supplement containing $50 \mathrm{~g}$ phosphate $(\mathrm{P}) / \mathrm{kg}$ and $150 \mathrm{~g}$ crude protein (CP)/kg. T2 and T3 both consisted of supplements containing $60 \mathrm{~g} \mathrm{P} / \mathrm{kg}$ and $0 \mathrm{~g} \mathrm{CP} / \mathrm{kg}$. In winter, T1 consisted of a supplement containing $367 \mathrm{~g} \mathrm{CP} / \mathrm{kg}, 77.5 \%$ non-protein nitrogen (NPN) and metabolizable energy (ME) content of $5.25 \mathrm{MJ} / \mathrm{kg}$. T2 had $466 \mathrm{~g} \mathrm{CP} / \mathrm{kg}$, $88.7 \% \mathrm{NPN}$ and a ME content of $4.4 \mathrm{MJ} / \mathrm{kg}$. T3 had $475 \mathrm{~g} \mathrm{CP} / \mathrm{kg}, 95.9 \% \mathrm{NPN}$ and an ME content of 2.4 $\mathrm{MJ} / \mathrm{kg}$. Traits were calf birth weight, 100-day and weaning weights of calves, cow weight at weaning, intercalving period (ICP), conception rate and body condition score (BCS) of cows. Calf birth weight was affected by supplementation treatment only in year 3 and 100-day weight in year 2 . However, weaning weight and reproductive performance were not influenced by treatment. It was concluded that the level of supplementation of each treatment group enabled the cows to operate within their target weight range; however, it was more profitable to use the T3 supplementation option.
\end{abstract}

Keywords: Cymbopogon-Themeda veld, cows, performance

\#Corresponding author: pfourie@cut.ac.za

\section{Introduction}

Farmers continually seek means of increasing the production and profitability of their livestock enterprises. Often, they focus on methods that increase production, based on the understanding that production is the profit equation component that affects income directly. Farmers also need to consider cost management and, most importantly, the profitability of the cow-calf enterprise (Ramsey et al., 2005).

Many reports have been published on the marked effect of supplementary feeding on animal reproduction and growth under extensive grazing conditions. Supplementary feeding is considered normal practice in the South African livestock farming industry (Lishman et al., 1984; Read et al., 1986a; Read et al., 1986b; De Brouwer et al., 1993; De Waal et al., 1996; Van Niekerk, 1996; De Brouwer et al., 2000). However, many erroneous conclusions have been reached about the need for supplementary feeding based on analytical data (Van Niekerk, 1996). Therefore, the nutritive value of the veld and its ability to support animal production, as well as the role of supplementary feeding in promoting animal production, should be studied under realistic and practical grazing conditions (De Waal, 1990). Needless to say, any input regarding supplementation should be reflected positively in animal performance, and the increase in output must be economically justifiable.

The purpose of this study was thus to investigate the effect of three levels of lick supplementation on the production and profitability of a beef herd that was farmed extensively on transitional CymbopogonThemeda veld. 


\section{Materials and Methods}

The study was conducted from August 2011 to July 2014 on Quaggafontein Farm, which is 3559 ha in size, and is situated $30 \mathrm{~km}$ south of Zastron in the south-eastern Free State, South Africa. The farm is located between $30^{\circ} 27^{\prime}$ south and $27^{\circ} 13^{\prime}$ east and at an altitude of between 1352 and 1626 metres above sea level. The average annual rainfall is $550 \mathrm{~mm}$; summer temperatures are temperate; and winters are cold, with frost occurring from the end of April until the beginning of October. The average daily temperatures by month are presented in Table 1. The vegetation is typical of transitional Cymbopogon-Themeda veld with a grazing capacity of 5 to $7 \mathrm{ha} /($ large stock unit).

Table 1 Average daily maximum and minimum temperatures $\left({ }^{\circ} \mathrm{C}\right)$ by month from 1 August 2011 to 31 July 2014 for south-eastern Free State, South Africa

\begin{tabular}{lcccccc}
\hline \multirow{2}{*}{ Month } & \multicolumn{2}{c}{ August 2011-July 2012 } & \multicolumn{2}{c}{ August 2012-July 2013 } & \multicolumn{2}{c}{ August 2013-July 2014 } \\
\cline { 2 - 7 } & Max $\left({ }^{\circ} \mathbf{C}\right)$ & Min $\left({ }^{\circ} \mathbf{C}\right)$ & Max $\left({ }^{\circ} \mathbf{C}\right)$ & Min $\left({ }^{\circ} \mathbf{C}\right)$ & Max $\left({ }^{\circ} \mathbf{C}\right)$ & Min $\left({ }^{\circ} \mathbf{C}\right)$ \\
\hline \multirow{2}{*}{ August } & & & & & & \\
September & 20.3 & 1.4 & 20.4 & 3.0 & 19.1 & 0.3 \\
October & 24.8 & 4.8 & 22.7 & 3.9 & 23.7 & 3.7 \\
November & 26.4 & 8.1 & 26.0 & 8.7 & 26.2 & 7.8 \\
December & 28.3 & 9.9 & 29.2 & 11.8 & 27.5 & 10.6 \\
January & 28.6 & 13.1 & 27.1 & 14.2 & 27.5 & 13.7 \\
February & 31.3 & 15.1 & 30.8 & 15.7 & 30.9 & 15.9 \\
March & 28.6 & 14.9 & 30.8 & 13.6 & 28.0 & 16.4 \\
April & 27.3 & 12.2 & 28.2 & 13.1 & 25.9 & 12.7 \\
May & 22.2 & 5.9 & 23.1 & 6.4 & 23.2 & 6.4 \\
June & 22.3 & 3.3 & 21.3 & 2.9 & 21.5 & 3.7 \\
July & 16.2 & 0.6 & 18.3 & -1.4 & 17.5 & -1.7 \\
& 17.2 & -0.9 & 19.1 & 0.9 & 17.0 & -2.6 \\
\hline
\end{tabular}

Source: South African Weather Service, 2015

Animal experimentation was conducted within standard ethical norms. A total of 150 Drakensberger cows were used, which had been raised on the site prior to the study. The cows were dry, had mated naturally, and were verified as pregnant before the commencement of the study. The cows were initially stratified into age groups and then randomly subdivided into one of three treatment groups, namely T1, T2, and T3, each with 50 cows $(n=50)$. Parity was not known and was assumed to be correlated with the age of the cow. The mean weights of the cows at the start of the study were $548 \mathrm{~kg} \pm 62,544 \mathrm{~kg} \pm 50$, and $543 \mathrm{~kg} \pm$ 57 for $\mathrm{T} 1, \mathrm{~T} 2$, and $\mathrm{T} 3$ cows, respectively.

A three-phase supplementation programme was used in which the production year was divided into three periods, namely summer (wet season) (approximately mid December to March), winter (early dry season) (April to July), and late winter (late dry season) (August to approximately mid December). The winter and late winter supplementations had the same nutrient compositions. However, during winter supplementation, the treatment groups were offered $80 \%$ of the amount of supplement that was offered during late winter supplementation. The levels of supplementation that were chosen in this study were similar to the levels commonly recommended by animal nutritionists and often used by farmers. However, the level of energy supplementation for some of the treatments was low in relation to the animals' daily requirements. Nevertheless, this is typical of the levels used under practical farming conditions.

Macro ingredients were mixed on site according to commercial supplementation formulations. The intake of the supplements was recorded accurately at herd level. The supplements were available ad libitum, but never exceeded the maximum recommended daily intake. They were replenished twice a week to ensure that the animals had access to adequate supplies. Weekly weather forecasts on the possibility of rainfall were considered in determining on which day supplements would be replenished. This was an attempt to prevent supplements containing urea from getting wet, which could affect intake and cause poisoning or death. Adjustments were made for wet supplements that had to be replaced. During the very dry spell 
experienced in the latter part of 2013 , the amount of supplement offered to all three treatment groups was increased by $10 \%$.

During the summer supplementation season, all three groups were offered mineral supplements. T1 was supplemented with VOERMOL SUPERFOS® with $150 \mathrm{~g} \mathrm{CP} / \mathrm{kg}$ and $50 \mathrm{~g} \mathrm{P} / \mathrm{kg}$. The T2 and T3 groups were offered identical mineral supplements containing $0 \mathrm{~g} \mathrm{CP} / \mathrm{kg}$ and $60 \mathrm{~g} \mathrm{P} / \mathrm{kg}$. The nutrient composition and raw material inclusion rate (\%) of the summer supplementation treatments are presented in Table 2.

All three groups were offered a protein and mineral supplement in winter and late winter. However, the nutrient composition of treatments varied because of different inclusion rates of raw materials (see Table 3 ).

Table 2 Raw material inclusion rate (\%), nutrient composition and recommended daily intake (g/cow/day) of summer supplementation treatments

\begin{tabular}{|c|c|c|c|}
\hline & Treatment 1 & Treatment 2 & Treatment 3 \\
\hline & \multicolumn{3}{|c|}{ Raw material inclusion rate (\%) } \\
\hline VOERMOL SUPERFOS ${ }^{\circledR}$ & 100 & - & - \\
\hline Kimtrafos $12 \AA$ & - & 50 & 50 \\
\hline Feed grade sulfur & - & 5 & 5 \\
\hline \multirow[t]{2}{*}{ Salt } & - & 45 & 45 \\
\hline & \multicolumn{3}{|c|}{ Nutrient composition } \\
\hline Crude protein (\%) & 15.0 & - & - \\
\hline From NPN (\%) & 13.6 & - & - \\
\hline MJME/kg DM & - & - & - \\
\hline \multirow[t]{2}{*}{$P(\%)$} & 5.0 & 6.0 & 6.0 \\
\hline & \multicolumn{3}{|c|}{ Recommended daily intake (g/cow/day) } \\
\hline Summer & $120-240$ & $100-240$ & $100-240$ \\
\hline
\end{tabular}

Table 3 Raw material inclusion rate (\%), nutrient composition and recommended daily intake ( $\mathrm{g} / \mathrm{cow} /$ day) of the winter and late winter supplementation treatments

\begin{tabular}{|c|c|c|c|}
\hline & Treatment 1 & Treatment 2 & Treatment 3 \\
\hline & \multicolumn{3}{|c|}{ Raw material inclusion rate (\%) } \\
\hline Maize meal & 24.88 & 23.65 & 18.46 \\
\hline Cottonseed oilcake & 14.93 & 9.46 & - \\
\hline Feed grade urea & 9.95 & 14.93 & 15.38 \\
\hline Kimtrafos $12 \AA$ & 9.95 & 14.93 & 15.38 \\
\hline Kalori $3000 \AA$ & 4.98 & 4.73 & 3.85 \\
\hline Feed grade sulfur & 0.49 & 0.66 & 0.77 \\
\hline \multirow[t]{2}{*}{ Salt } & 34.83 & 33.11 & 46.15 \\
\hline & \multicolumn{3}{|c|}{ Nutrient composition } \\
\hline Crude protein (\%) & 36.7 & 46.6 & 47.5 \\
\hline From NPN (\%) & 77.5 & 88.7 & 95.86 \\
\hline $\mathrm{ME}(\mathrm{MJ} / \mathrm{kg})$ & 5.25 & 4.4 & 2.4 \\
\hline \multirow[t]{2}{*}{$\mathrm{P}(\%)$} & 1.4 & 1.9 & 2.57 \\
\hline & \multicolumn{3}{|c|}{ Recommended daily intake (g/cow/day) } \\
\hline Winter & $380-520$ & $280-400$ & $280-400$ \\
\hline Late winter & $450-650$ & $350-500$ & $350-500$ \\
\hline
\end{tabular}


Treatments consisted of three levels of supplemental CP, percentage protein derived from NPN and ME, namely T1 (367 g CP/kg, of which $77.5 \%$ was derived from NPN and ME of $5.3 \mathrm{MJ} / \mathrm{kg})$, T2 $(466 \mathrm{~g}$ $\mathrm{CP} / \mathrm{kg}$, of which $88.7 \%$ was derived from NPN and ME $4.4 \mathrm{MJ} / \mathrm{kg})$, and T3 $(475 \mathrm{~g} \mathrm{CP} / \mathrm{kg}$, of which $95.9 \%$ was derived from NPN and ME 2.4 MJ/kg).

A rangeland condition assessment was made by Van der Westhuizen et al. (2013) and the rangeland was found to be in excellent condition (see Table 4).

Table 4 Species composition (\%) and rangeland condition (\%) of the study site

\begin{tabular}{|c|c|c|c|}
\hline Site & & Foot slope & Crest \\
\hline Species & I & & \\
\hline Cymbopogon pospischilii & & 10.6 & 23.5 \\
\hline Helictotrichon turgidulum & 10 & 1.9 & 0.0 \\
\hline Sporobolus fimbriatus & & 1.9 & 2.0 \\
\hline Sub total & & 14.4 & 25.5 \\
\hline Harpochloa falx & 0 & 9.6 & 10.8 \\
\hline Themeda triandra & 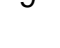 & 3.8 & 6.9 \\
\hline Sub total & & 14 & 17.7 \\
\hline Triraphis andropogonoides & 8 & 1.0 & 0.0 \\
\hline Sub total & & 1.0 & 0.0 \\
\hline Aristida diffusa & & 4.8 & 0.0 \\
\hline Heteropogon contortus & 7 & 5.8 & 0.0 \\
\hline Walafrida saxatilis & & 0.0 & 1.0 \\
\hline Sub total & & 10.6 & 1.0 \\
\hline Brachiaria serrata & & 6.7 & 1.0 \\
\hline Elionurus muticus & 6 & 23.1 & 20.3 \\
\hline Microchloa caffra & & 0.0 & 1.0 \\
\hline Sub total & & 29.8 & 22.3 \\
\hline Digitaria eriantha & & 1.9 & 0.0 \\
\hline Helichrysum dregeanum & 5 & 1.9 & 0.0 \\
\hline Annual herbs & & 1.0 & 1.0 \\
\hline Sub total & & 4.8 & 1.0 \\
\hline Eragrostis plana & 4 & 5.8 & 0.0 \\
\hline Setaria pallide-fusca & 3 & 7.7 & 2.0 \\
\hline Eragrostis gummiflua & 2 & 4.8 & 0.0 \\
\hline Eragrostis chloromelas & 0 & 2.9 & 6.9 \\
\hline Other species & & 2.9 & 7.8 \\
\hline Helichrysum lucilioides & & 1.0 & 12.7 \\
\hline Seriphium plumosum & & 1.0 & 0.0 \\
\hline Tragus koelerioides & & 2.9 & 7.8 \\
\hline Tristachya leucothrix & & 0.0 & 2.9 \\
\hline Sub total & & 100 & 100 \\
\hline Rangeland condition & & -88 & 87 \\
\hline
\end{tabular}

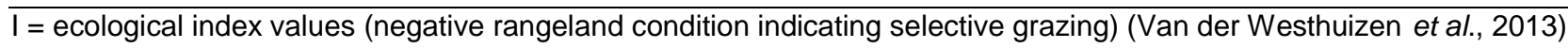


The veld was managed according to the principles of the three-camp-Elionurus cattle grazing system developed by Van der Westhuizen (2014) and the stocking rate was maintained at $7.2 \mathrm{ha} / \mathrm{animal}$ unit. Groups were rotated between camps fortnightly to minimise a possible 'camp effect' on their performance. The cows were mated naturally during the summer (mid-December to end March) and calves were weaned according to age from April to June. Single-bull mating was applied at a ratio of $1: 25$. Each treatment group was divided into two sub-herds. Bulls were rotated between treatment groups fortnightly.

The parameters were supplement intake (g/cow/day) and cost (R/cow/year), cow weight (August, March, at weaning and July), BCS (scale 1-9); calf birth weight, calf 100-day weight, calf weaning weight, inter-calf period (days), and conception rate (\%).

Data were captured electronically in Microsoft Excel. Analyses were done with SAS Version 9.2. Frequencies and percentages were calculated for categorical data. Means and standard deviations or medians and percentiles were calculated for numerical data. Analytical statistics, namely an analysis of variance (ANOVA), was used to compare the mean values and the mean differences among the three treatment groups. The unpaired t-test was used to compare the mean values and the mean differences between two treatment groups at a time. The paired $\mathrm{t}$-test was used to investigate significant mean differences within each treatment group. A significance level (a) of 0.05 was used.

\section{Results and Discussion}

The period in which the animals were given access to the treatments differed annually, because the initiation and conclusion of a supplementation phase were prescribed by the condition of the grazing. The late winter supplemental CP intakes of all three groups were similar (234, 230, and $229 \mathrm{~g} /$ animal/day). However, owing to differences in the compositions of the treatments, variations occurred between the treatment groups in supplemental protein from NPN (181, 204, and $220 \mathrm{~g} /$ animal/day) and supplemental energy $(3.4,2.2$, and $1.2 \mathrm{MJ} / \mathrm{cow} /$ day). The three-year average cost incurred in supplying the late winter supplement to T1 was R248 per cow, to T2 was R200 per cow, and to T3 was R171 per cow (Table 5).

During summer supplementation, T1 consumed quantities $(229 \mathrm{~g} / \mathrm{cow} /$ day) close to the maximum recommended daily intake of $240 \mathrm{~g} / \mathrm{cow} /$ day (Table 5). T2 and T3 consumed quantities (101 and 104 $\mathrm{g} /$ cow/day) close to the minimum recommended daily intake of $100 \mathrm{~g} / \mathrm{animal} / \mathrm{day}$, resulting in a higher supplemental P intake for T1 (11.5 g/cow/day) compared with T2 and T3 (6.1 and $6.2 \mathrm{~g} / \mathrm{cow} /$ day). The threeyear average cost incurred in supplying the summer supplements to T1 was R107 per cow. The supplement to T2 was R33 per cow and to T3 was R34 per cow (Table 5). The three-year average supplement and nutrient intakes (g/cow/day) of the three groups during the study (2011-2014) are presented in Table 5 as well as the three-year average costs incurred (R/cow/period) per supplementation period.

Table 5 Average supplement values, nutrient intakes and costs per supplementation period

\begin{tabular}{lccccccccc}
\hline \multirow{2}{*}{$\begin{array}{l}\text { Component intake } \\
\text { (g/cow/day) }\end{array}$} & \multicolumn{3}{c}{ Late winter (137 days) } & \multicolumn{2}{c}{ Summer (106 days) } & \multicolumn{3}{c}{ Winter (123 days) } \\
\cline { 2 - 9 } & T1 & T2 & T3 & T1 & T2 & T3 & T1 & T2 & T3 \\
\hline \multirow{2}{*}{ Supplement } & 638 & 493 & 483 & 229 & 101 & 104 & 514 & 428 & 347 \\
Protein & 234 & 230 & 229 & 34 & 0 & 0 & 189 & 199 & 165 \\
Protein from NPN & 181 & 204 & 220 & 31 & 0 & 0 & 146 & 177 & 158 \\
MJME/Kg DM & 3.4 & 2.2 & 1.2 & 0 & 0 & 0 & 2.7 & 1.9 & 0.8 \\
P & 8.9 & 9.4 & 12.4 & 11.5 & 6.1 & 6.2 & 7.2 & 8.1 & 8.9 \\
Cost (R/cow/period) & 248 & 200 & 171 & 107 & 33 & 34 & 185 & 161 & 116 \\
\hline
\end{tabular}

The average winter supplement intake of T1 (514 g/cow/day) was close to the maximum recommended level of $520 \mathrm{~g} / \mathrm{cow} /$ day. T2 consumed $428 \mathrm{~g} / \mathrm{cow} /$ day, a little more than the maximum recommended level of $400 \mathrm{~g} / \mathrm{cow} /$ day, and T3 consumed $347 \mathrm{~g} / \mathrm{animal} / \mathrm{day}$, which was slightly less than the maximum recommended level. The three-year average cost incurred in supplying the winter supplement to T1 was R185 per cow, the supplement to T2 was R161, and the supplement to the T3 was R116 (Table 5). Supplement intakes of the groups were close to the levels recommended by animal nutritionists. 
Climatic and geographical variations in the nutritive value of natural pastures may be accommodated by varying the quantity of supplements (Cronje, 1990). Satisfactory cow production and reproduction results (see Table 7) were achieved by increasing supplements by only $10 \%$ during the drought of 2013 . Thus a constant level of animal production was possible at relatively minimal cost. The realistic stocking rate according to the grazing capacity of the veld and the implementation of the three-camp-Elionorus-cattle rangeland management system (Van der Westhuizen, 2014) is believed to have played a pivotal role in the level of animal production that was achieved in 2013.

The mean bodyweights $(\mathrm{kg})$ and weight gains and losses of the groups during the study are presented in Table 5 and the mean BCS in Table 6.

Table 5 Mean bodyweights and weight gains/losses of the supplementation treatment groups from August 2011 to July 2014

\begin{tabular}{|c|c|c|c|}
\hline \multirow{2}{*}{ Treatments } & T1 & T2 & T3 \\
\hline & Mean weight $(\mathrm{kg})$ & Mean weight $(\mathbf{k g})$ & Mean weight (kg) \\
\hline & \multicolumn{3}{|c|}{1 August 2011 to 31 July 2012} \\
\hline & $\mathrm{n}=40$ & $\mathrm{n}=46$ & $\mathrm{n}=40$ \\
\hline Late winter (August) & $548^{a} \pm 62$ & $544^{\mathrm{a}} \pm 50$ & $543^{\mathrm{a}} \pm 57$ \\
\hline Summer (March) & $543^{\mathrm{a}} \pm 57$ & $562^{\mathrm{a}} \pm 52$ & $569^{b} \pm 49$ \\
\hline Wean & $535^{a} \pm 58$ & $562^{b} \pm 56$ & $* 529^{a} \pm 57$ \\
\hline Winter (July) & ${ }^{*} 513^{a} \pm 51$ & ${ }^{*} 546^{\mathrm{b}} \pm 53$ & ${ }^{*} 512^{\mathrm{a}} \pm 55$ \\
\hline \multirow[t]{3}{*}{ Weight gain/loss Aug to March } & $-5^{a} \pm 35$ & $* * 18^{\mathrm{b}} \pm 30$ & $* * * 26^{b} \pm 26$ \\
\hline & \multicolumn{3}{|c|}{1 August 2012 to 31 July 2013} \\
\hline & $\mathrm{n}=41$ & $n=43$ & $\mathrm{n}=46$ \\
\hline Late winter (August) & $523^{\mathrm{a}} \pm 57$ & $537^{\mathrm{a}} \pm 51$ & $527^{\mathrm{a}} \pm 59$ \\
\hline Summer (March) & $570^{\mathrm{a}} \pm 68$ & $566^{\mathrm{a}} \pm 60$ & $560^{\mathrm{a}} \pm 47$ \\
\hline Wean & $540^{\mathrm{a}} \pm 58$ & $552^{\mathrm{ab}} \pm 52$ & $563^{b} \pm 53$ \\
\hline Winter (July) & $551^{\mathrm{a}} \pm 59$ & $548^{\mathrm{a}} \pm 56$ & $546^{\mathrm{a}} \pm 47$ \\
\hline \multirow[t]{3}{*}{ Weight gain/loss August to March } & $48^{\mathrm{a}} \pm 42$ & $29^{b} \pm 28$ & $33^{\mathrm{ab}} \pm 40$ \\
\hline & \multicolumn{3}{|c|}{1 August 2013 to 31 July 2014} \\
\hline & $\mathrm{n}=34$ & $\mathrm{n}=37$ & $\mathrm{n}=39$ \\
\hline Late winter (August) & $550^{\mathrm{a}} \pm 58$ & $551^{\mathrm{a}} \pm 67$ & $545^{\mathrm{a}} \pm 50$ \\
\hline Summer (March) & $553^{\mathrm{a}} \pm 53$ & $566^{a} \pm 59$ & $569^{a} \pm 43$ \\
\hline Wean & $551^{\mathrm{a}} \pm 55$ & $566^{\mathrm{a}} \pm 61$ & $556^{\mathrm{a}} \pm 46$ \\
\hline Winter (July) & $541^{\mathrm{a}} \pm 54$ & $540^{\mathrm{a}} \pm 54$ & $549^{\mathrm{a}} \pm 46$ \\
\hline Weight gain/loss Aug to March & $3^{a} \pm 39$ & $17^{\mathrm{ab}} \pm 45$ & $24^{b} \pm 31$ \\
\hline
\end{tabular}

${ }^{\text {ab }}$ Means in the same row with different superscripts differ significantly: $P<0.05 ;{ }^{*} P<0.01,{ }^{* *} P<0.001,{ }^{* * *} P<0.0001$

In year $1(2011-12)$ of the study T2 was heavier $(P<0.01)$ at the weaning of their calves than T1 and T3. This was also the case at the end (July) of year 1 (Table 5).

In year $2(2012-13)$ T3 were heavier $(P<0.05)$ at the weaning of their calves than T2. No significant differences in bodyweights were measured between the groups in year 3 (2013-14) (Table 5). T3 gained the most weight from August to March in year $1(P<0.0001)$ and year $3(P<0.05)$, and had the highest BCS $(P$ $>0.05$ ) at the end of the breeding season (March) in year 1 and year 3 (Tables 5 and 6). T1 gained the least amount of weight from August to March in year $1(P<0.0001)$ and year $3(P<0.05)$ and had the lowest BCS $(P>0.05)$ at the end of the breeding season (March) in year 1 and year 3 . In year 2, T1 gained the most weight from August to March $(P<0.05)$ and T2 the least. Even though T2 gained the least weight, it had the highest BCS $(5.05 \pm 0.49)$ at the end of the breeding season $(P<0.01)$ (Table 5 and 6$)$. Table 7.

The production and reproduction levels attained by the groups during the study are summarized in 
Table 6 Mean Body condition score of the supplementation treatment groups from August 2011 to July 2014

\begin{tabular}{|c|c|c|c|}
\hline \multirow[b]{2}{*}{ Treatments } & \multicolumn{3}{|c|}{ Mean BCS } \\
\hline & T1 & T2 & T3 \\
\hline & \multicolumn{3}{|c|}{1 August 2011 to 31 July 2012} \\
\hline Late winter (August) & $4.80^{\mathrm{a}} \pm 0.85$ & $4.72^{\mathrm{ab}} \pm 0.81$ & $4.30^{b} \pm 0.69$ \\
\hline Summer (March) & $4.95^{\mathrm{a}} \pm 0.55$ & $5.02^{\mathrm{a}} \pm 0.58$ & $5.23^{a} \pm 0.95$ \\
\hline \multirow[t]{2}{*}{ Winter (July) } & $4.30^{\mathrm{a}} \pm 0.56$ & $4.54^{\mathrm{a}} \pm 0.78$ & $4.48^{a} \pm 0.55$ \\
\hline & \multicolumn{3}{|c|}{1 August 2012 to 31 July 2013} \\
\hline Late winter (August) & $4.56^{\mathrm{a}} \pm 0.78$ & $4.81^{a} \pm 0.82$ & $4.89^{a} \pm 0.85$ \\
\hline Summer (March) & $4.90^{\mathrm{ab}} \pm 0.66$ & $\star 5.05^{\mathrm{a}} \pm 0.49$ & $* 4.76^{\mathrm{b}} \pm 0.52$ \\
\hline \multirow[t]{2}{*}{ Winter (July) } & $4.70^{a} \pm 0.72$ & $4.67^{\mathrm{a}} \pm 0.52$ & $4.70^{a} \pm 0.46$ \\
\hline & \multicolumn{3}{|c|}{1 August 2013 to 31 July 2014} \\
\hline Late winter (August) & $4.85^{\mathrm{a}} \pm 0.86$ & $4.81^{a} \pm 0.88$ & $4.95^{\mathrm{a}} \pm 0.72$ \\
\hline Summer (March) & $4.59^{a} \pm 0.61$ & $4.59^{\mathrm{a}} \pm 0.55$ & $4.67^{a} \pm 0.58$ \\
\hline Winter (July) & $4.88^{\mathrm{a}} \pm 0.77$ & $4.81^{\mathrm{a}} \pm 0.57$ & $4.71^{a} \pm 0.46$ \\
\hline
\end{tabular}

1 = emaciated, 2 = poor condition, 3 = thin condition, 4 = borderline condition, 5 = moderate condition, $6=$ high moderate condition, 7 = good condition, 8 = fat, $9=$ extremely fat ; ${ }^{\mathrm{ab}}$ Means in the same row with different superscripts differ significantly: $P<0.05 ;{ }^{*} P<0.01$

Table 7 Means for birth weight, 100-day weights and weaning weights of calves, and cow weights at weaning, inter-calving periods and conception rates of supplementation treatment groups from August 2011 to July 2014

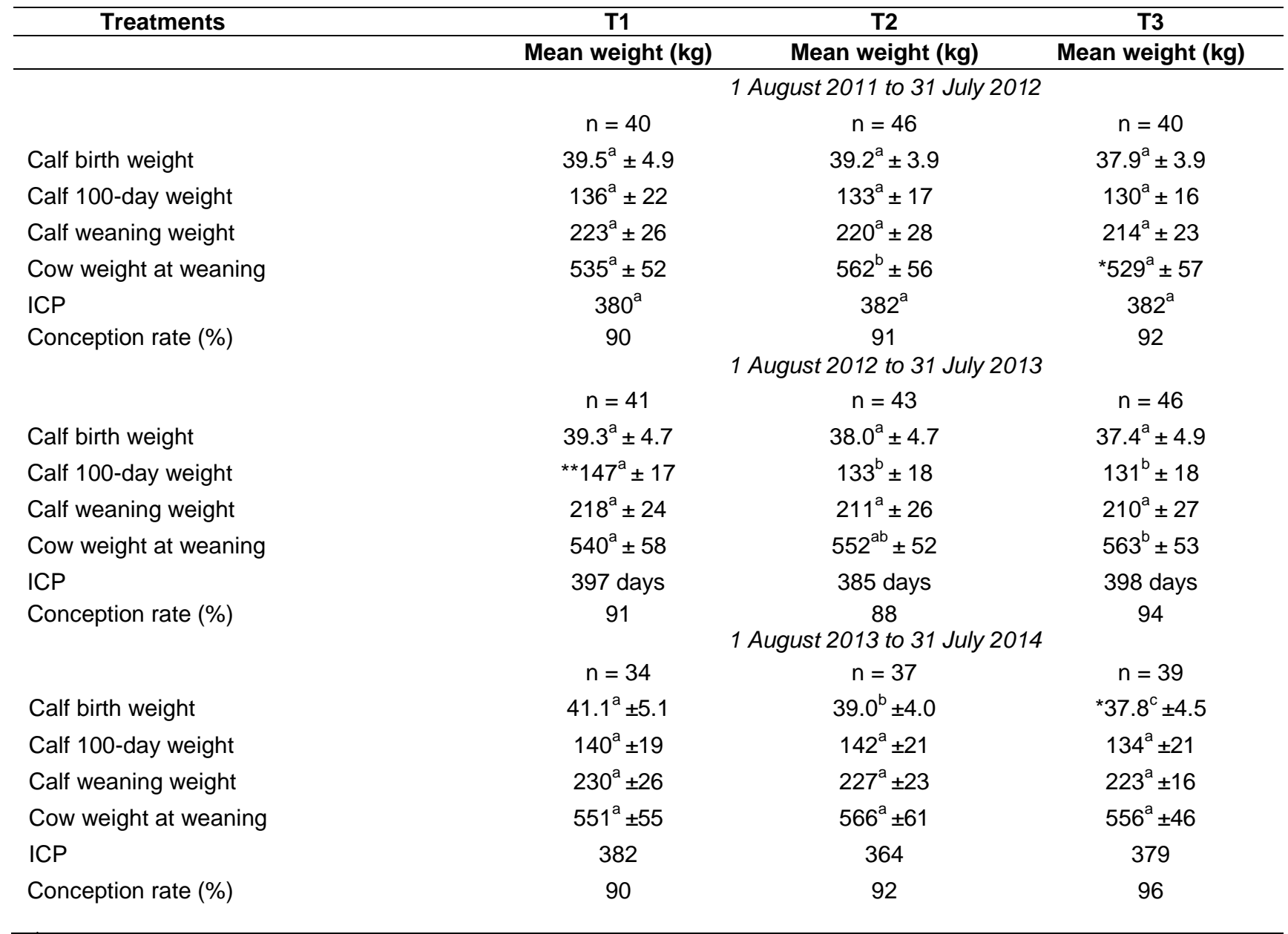

\footnotetext{
${ }^{\text {ab }}$ Means in the same row with different superscripts differ significantly: $P<0.05$; ${ }^{\star} P<0.01,{ }^{\star \star} P<0.001$; Inter calving period (ICP)
} 
Conception rate and weaning weight were used as measures of reproductive efficiency. Although there were no statistical differences in weaning weights between treatments, there was a trend for T1 calves to be the heaviest at weaning and T3 calves to be the lightest in the three years. Conception rates of $90 \%$, $91 \%$ and $92 \%$ were recorded for $\mathrm{T} 1 ; 91 \%, 88 \%$ and $92 \%$ for $\mathrm{T} 2$; and $92 \%, 94 \%$ and $96 \%$ for $\mathrm{T} 3$, respectively $(P>0.05)$. While differences $(P<0.001)$ in 100 -day calf weights were observed between groups in 2012-13 and in the birth weights $(P<0.01)$ of the calves in 2013-14, these variables were not used as production parameters. The three-year average ICP for T1 was 387 days, for T2 was 378 days, and for T3 was 387 days $(P>0.05)$.

There were no significant relationships between bodyweight and conception rate and body condition score and conception rate. The lack of relationships among these parameters may be explained by the 'target weight' concept proposed by Lamond (1970). According to Lamond (1970), each cow has a probability of conception within a range of bodyweight and body condition. It is thus believed that the level of supplementation of all three groups enabled the cows in each group to operate within their target weight range. Similar results were reported by Steenkamp et al. (1975), Meaker et al. (1980) and Lishman (1984).

Though not significant, there was a tendency for conception rate to increase as bodyweight increased from before calving to the end of the breeding season (August to March) and to have a higher BCS at the end of the breeding season. Preston \& Willis (1974), Lishman (1984), Groenewald (1986) and MacGregor \& Swanepoel (1992) reported similar findings. In years 1 and 3, T3 had the highest BCS $(P<0.05)$ at the end of the breeding season, the highest weight gains from August (before calving) to March (end of the breeding season) and the highest conception rate. T1, in contrast, had the lowest BCS at the end of the breeding season, the lowest weight gains from August to March and the lowest conception rate in year 1 and year 3 . In year 2, however, a slight deviation was seen in the trend in year 1 and year 3. In year 2, T2 had the lowest weight gain from August to March, the lowest conception rate, but the highest BCS at the end of the breeding season. The reasons could not be explained.

Although cows in T1 weaned slightly heavier calves, the improvement was not enough to make this practice economically justifiable because these weights were not sufficient to cover the higher expenses associated with T1. These results are in agreement with De Brouwer at al. (1993), who found supplementing cows on the western Highveld (Potchefstroom) with a dicalcium phosphate supplement in summer and a urea-based protein supplement in winter gave satisfactory production and reproduction results, but at a reduced cost.

\section{Conclusions}

South-eastern Free State veld that is in good condition and is well managed gives the highest economic return by supplementing beef breeder cows with a mineral $(60 \mathrm{~g} \mathrm{P} / \mathrm{kg})$ supplement in the wet season and a protein and mineral supplement of which most (96\%) of the protein is derived from NPN (urea) in the dry season. However, different results may be obtained with other breed types.

\section{Acknowledgements}

The authors wish to acknowledge the inputs of Mr Hendrik van Pletzen and Mr Johan Mouton.

\section{Authors' Contributions}

The trial was executed by LAF, while PJF and FWCN provided supervision.

\section{Conflict of Interest Declaration}

The authors declare that there is no conflict of interest.

\section{Disclaimer}

The authors of this paper do not endorse the use of any of the supplements used in this study.

\section{References}

Cronje, P.B., 1990. Review. Supplementary feeding in ruminants - A physiological approach. S. Afr. J. Anim. Sci. 23(3), 110-117.

De Brouwer, C.H.M., Visser, C.B., Schutte, A.R. \& Postma, M., 1993. Biological and economical effects of different supplements given to beef cows on summer veld. S. Afr. J. Anim. Sci. 23(2), 31-37.

De Brouwer, C.H.M., Cilliers, J.W., Vermaak, L.M., Van der Merwe, H.J. \& Groenewald, P.C.N., 2000. Phosphorus supplementation to natural pasture for beef cows in the western Highveld region of South Africa. S. Afr. J. Anim. Sci., 30(1), 43-52.

De Waal, H.O., 1990. Animal production from native pasture (veld) in the Free State Region - A perspective of the grazing ruminant. S. Afri. J. Anim. Sci. 20(1), 1-9.

De Waal, H.O., Randall, J.H. \& Koekemoer, G.J., 1996. The effects of phosphorus supplementation on body mass and reproduction of grazing beef cows supplemented with different levels of phosphorus at Armhoedsvlekte S. Afr. J. Anim. Sci. 26(2), 29-36. 
Groenewald, I.B., 1986. Die invloed van stikstof-, energie-, en fosforbevattende lek- aanvullings op die reproduksie- en produksievermoe van koeie op natuurlike weiding. Ph.D.-proefskrif, Universiteit van die Oranje Vrystaat, Bloemfontein.

Lamond, D.R., 1970. The influence of undernutrition on reproduction in the cow. Animal Breeding, Abstract, 38, $255-267$.

Lishman, A.W., Lyle, A.D., Smith, V.W. \& Botha, W.A., 1984. Conception rate of beef cows and growth of suckling calves as influenced by date of calving and supplementary feeding. S. Afri. J. Anim. Sci. 14(1), 10-19.

Macgregor, R.G. \& Swanepoel, F.J.C., 1992. The relationship between body mass and fertility in Bonsmara breeding females. S. Afric. J. Anim. Sci. 22(2), 64-69.

Meaker, H.J., Coetsee, T.P.N., Smith, M \& Lishman, A.W., 1980. The relationship between body mass and fertility of beef cows of different ages. S. Afri. J. Anim. Sci. 10, 83-89.

Preston, T.R. \& Willis, M.B. 1974. Intensive beef production. Pergamon Press, New York.

Ramsey, R., Doye, D., Ward, C., Mcgrann, J., Falconer, L. \& Bevers, S., 2005. Factors affecting beef cow-herd costs, production, and profits. J. Agric. Appl. Econ. 37(1), 91-99.

Read, M.V.P. \& Engels, E.A.N. \& Smith, W.A., 1986a. Phosphorus and the grazing ruminant. 2. The effects of supplementary P on cattle at Glen and Armoedsvlekte. S. Afri. J. Anim. Sci. 16(1), 7-12.

Read, M.V.P. \& Engels, E.A.N. \& Smith, W.A., 1986b. Phosphorus and the grazing ruminant. 3. Rib bone samples as an indicator of the P status of cattle. S. Afri. J. Anim. Sci. 16(1), 13-17.

Steenkamp, J.D.G, Van der Horst, C \& Andrew, M.J.A., 1975. Reconception in grade and pedigree Afrikander cows of different sizes - postpartum factors influencing conception. S. Afri. J. Anim. Sci. 5, 103.

Van der Westhuizen, H.C., Snyman, H.A. \& Fouché, H.J., 2013. Subjective determination of rangeland condition on the slopes of hills on the farm Quaggafontein, Zastron. Final report.

Van der Westhuizen, H.C., 2014. Evaluering van onderskeie veldbestuursbenaderings. Boer saam met die natuur op soetgrasveld. In: H.A. Snyman (ed.) Gids tot die volhoubare produksie van weiding. Tweede uitgawe. Kaapstad: Landbouweekblad en Landbou.com, Media 24, 127-131.

Van Niekerk, B.D.H., 1996. Limiting nutrients in supplementary feeding. Bul. Grassl. Soc. SA. 7(1), 51-59. 